\title{
Butterflies (Lepidoptera, Papilionoidea and Hesperioidea) of the "Baixada Santista" region, coastal São Paulo, southeastern Brazil
}

\author{
Ronaldo Bastos Francini ${ }^{1}$, Marcelo Duarte², Olaf Hermann Hendrik Mielke², \\ Astrid Caldas ${ }^{4} \&$ André Victor Lucci Freitas ${ }^{5}$
}

\begin{abstract}
${ }^{1}$ Curso de Ciências Biológicas, Universidade Católica de Santos, Campus D. Idílio José Soares, Av. Conselheiro Nébias, 300, $11065-902$ Santos-SP, Brasil. francini@unisantos.edu.br

${ }^{2}$ Museu de Zoologia da Universidade de São Paulo, Avenida Nazaré 481, 04263-000 São Paulo-SP, Brasil. mduartes@usp.br

${ }_{3}^{3}$ Departamento de Zoologia, Universidade Federal do Paraná, Caixa Postal 19020, 81531-980 Curitiba-PR, Brasil. omhesp@ufpr.br

${ }^{4}$ Department of Entomology, National Museum of Natural History, Smithsonian Institution, PO Box 37012 NHB Stop 127, Washington, DC, 20013-7012 USA. astridcaldas@gmail.com

${ }_{5}^{5}$ Departamento de Biologia Animal and Museu de Zoologia, Instituto de Biologia, Universidade Estadual de Campinas, Caixa Postal 6109, 13083-970 Campinas-SP, Brasil. baku@unicamp.br (corresponding author)
\end{abstract}

\begin{abstract}
Butterflies (Lepidoptera, Papilionoidea and Hesperioidea) of the "Baixada Santista" region, coastal São Paulo, southeastern Brazil. A list with 538 species of butterflies recorded in the Baixada Santista, São Paulo (SE Brazil) is presented. Standard sampling protocols (i.e. with entomological nets) were followed. Baited traps were installed for fruit feeding species. Data from the literature and entomological collections were also considered in the total estimated species richness. The species richness recorded in the Baixada Santista region represents about $16 \%$ of the Brazilian butterfly fauna, and 34\% of the known butterfly fauna for the state of São Paulo. The present list contains an appreciably higher number of species in comparison to other lists from similar biomes farther south, such as Blumenau in Santa Catarina, and Maquiné in Rio Grande do Sul.
\end{abstract}

KEYWORDS. Atlantic Forest; conservation; diversity; Neotropical region.

RESUMO. Borboletas (Lepidoptera, Papilionoidea e Hesperioidea) da região da Baixada Santista, litoral de São Paulo (SE Brasil). Uma lista com 538 espécies de borboletas registradas na Baixada Santista é apresentada. Foram seguidos os protocolos amostrais padronizados (i.e. redes entomológicas). Armadilhas com iscas foram instaladas para coleta de espécies frugívoras. Dados de literatura e coleções entomológicas também foram considerados nas estimativas de riqueza de espécies. A riqueza de espécies registrada na Baixada Santista representa cerca de 16\% da fauna de borboletas do Brasil, e 34\% da fauna de borboletas do Estado de São Paulo. A presente lista contém um número consideravelmente alto de espécies em comparação com outras listas de biomas similares mais ao sul, como Blumenau em Santa Catarina, e Maquiné no Rio Grande do Sul.

PALAVRAS-CHAVE. Conservação; diversidade; Mata Atlântica; região Neotropical.

Interest in the conservation and monitoring of biological diversity has increased dramatically in the past 20 years. Nonetheless, species inventories and lists, arguably one of the most essential tools for any practical decision about species conservation (Lewinsohn \& Prado 2002), are still lacking for most groups, including butterflies (Brown \& Freitas 1999).

The Brazilian Atlantic Forest is a heterogeneous and endangered biome (Brown \& Freitas 2000b), and according to Morellato \& Haddad (2000) and Tabarelli et al. (2005) less than $10 \%$ of it remains. In the past ten years, a number of butterfly inventories in the Atlantic Forest have been published (see Santos et al. 2008 for a recent review on this topic), but much more information is needed for a better understanding of the general patterns of butterfly distribution in this biome.

There are about 3,300 species of butterflies in Brazil (Brown 1996; Brown \& Freitas 1999; Lewinsohn et al. 2005), and more than 2,100 species can be found in the Atlantic Forest (Brown 1992). In the state of São Paulo, where these insects have been reasonably well sampled (Brown 1992; Brown \& Freitas 1999, 2000b), about 1,600 species can be found. But even in São Paulo there are still a variety of habitats, such as the wet forests in the coastal region, that lack adequate information on butterfly richness and faunistic composition (Brown \& Freitas 1999).

Butterflies have been considered one of the most appropriate taxonomic groups for assessment of environmental disturbances in many parts of the world (Brown 1991; Freitas et al. 2006; Uehara-Prado et al. 2007 and references therein). They are excellent indicators in conservation planning (see Caldas \& Robbins 2003 for examples) and are seen as valuable biodiversity indicators (McGeoch 1998). They are also an effective "umbrella group" for habitat and diversity conservation (New 1997). However, a first and critical step for using these organisms as indicators is to obtain local and regional lists of species.

In the present study we provide a list of the butterfly species found in the "Baixada Santista" region. Our objective is 
not only to improve the knowledge of these insects in the coastal area of the state of São Paulo, but also to offer a tool for conservation and biodiversity decision-making.

For the purpose of this study, the Baixada Santista region includes the municipalities of Bertioga, Cubatão, Guarujá, Mongaguá, Praia Grande, Santos and São Vicente (Fig. 1, but see Kronka et al. 2005 for a definition based on hydrological resources). That entire region has been systematically explored since 1530, when the Portuguese colonizers arrived in Brazil, but the indigenous inhabitants probably used its natural resources extensively even before them (Petrone 1965).

The Baixada Santista is characterized by coastal plains, being delimited to the north by a continuous SW-NE mountain range with elevations varying from $800 \mathrm{~m}$ to $1,200 \mathrm{~m}$ (Serra do Mar), and to the south by the Atlantic Ocean. The regional climate is warm and wet, without a marked dry season (Santos 1965; SIGRH 2005; DAEE 2009). The average annual rainfall is about $2,500 \mathrm{~mm}$, but towards the mountains it can reach values as high as $3,000-4,000 \mathrm{~mm}$ in some of the valleys and montane slopes. The average annual temperature is $22^{\circ} \mathrm{C}$, with a maximum of $40^{\circ} \mathrm{C}$ and a minimum of $4^{\circ} \mathrm{C}$. Frosts have never been recorded in the region (Santos 1965).

According to Veloso et al. (1991), at least five primary distinct formations or physiognomies can be found in the region: sub-montane dense rain forest (mountain slopes from $50 \mathrm{~m}$ to $500 \mathrm{~m}$ ); lowlands rain forest (clay soils, from $5 \mathrm{~m}$ to $50 \mathrm{~m}$ ); sandy scrub forests ("restingas") and dunes (sandy soils, from sea level to $10 \mathrm{~m}$ ); mangroves and salt marshes (all estuarine systems); and vegetation growing on rocky shores in the seashore. Besides these formations, the region is extensively covered by many anthropic systems with various levels of disturbance and regeneration.

\section{MATERIAL AND METHODS}

Species records were obtained through field collections conducted by RBF (1968-2009) and AVLF (1988-2009). At least one specimen of each species was collected, and deposited in one of the following Brazilian collections (exact numbers of vouchers can be obtained from their curators): Museu de Zoologia da USP (MZSP), São Paulo, São Paulo or Museu de Zoologia da Unicamp (ZUEC), Campinas, São Paulo. Additional data were obtained from specimens deposited in the collections of two institutions in Brazil: Museu de Zoologia da Universidade de São Paulo (MZSP), São Paulo, São Paulo, and Coleção de Entomologia Pe. J. S. Moure (DZUP), Departamento de Zoologia, Universidade Federal do Paraná, Curitiba, Paraná. Species without actual data on geographical distribution or only present in neighboring areas were not included.

A total of 48 sites throughout the entire Baixada Santista were sampled from 1968 to 2009, and they included all physiognomies described above (Fig. 1) that extended from 0 to $500 \mathrm{~m}$ above sea level. We had at least one sampling day in each one of these sites, with some sites being more intensively sampled than others. Well sampled sites (a total of 35 with more than five days of sampling) are shown in Fig. 1, and further details on each of these sites are provided on Table I. Among those, the most sampled sites are in the area of Xixová-Japui State Park (sites 7-10 in Fig. 1), the area of the Rio Quilombo Valley (sites 21-22), the Voturuá Municipal Park (site 14), and the "Poço das Antas" area (sites 2-4), each one with more than 500 hours of sampling (details of the first three regions can be found in Freitas 1993, 1996 and Ramos \& Freitas 1999).

Sampling protocols followed Brown (1972), Brown \& Freitas (1999), and Freitas et al. (2003), with emphasis on diurnal collections made with nets, although butterfly traps were also used several times for sampling fruit feeding species.

The taxonomy follows mostly Lamas (2004), but also Willmott (2003) for the genus Adelpha, Mielke (2005) for Hesperioidea, Wahlberg et al. (2009) for the higher taxonomic categories for Nymphalidae, Duarte \& Robbins (2010) for some hairstreaks (Lycaenidae, Theclinae, Eumaeini), and Hall (2005) for some metalmarks (Riodinidae).

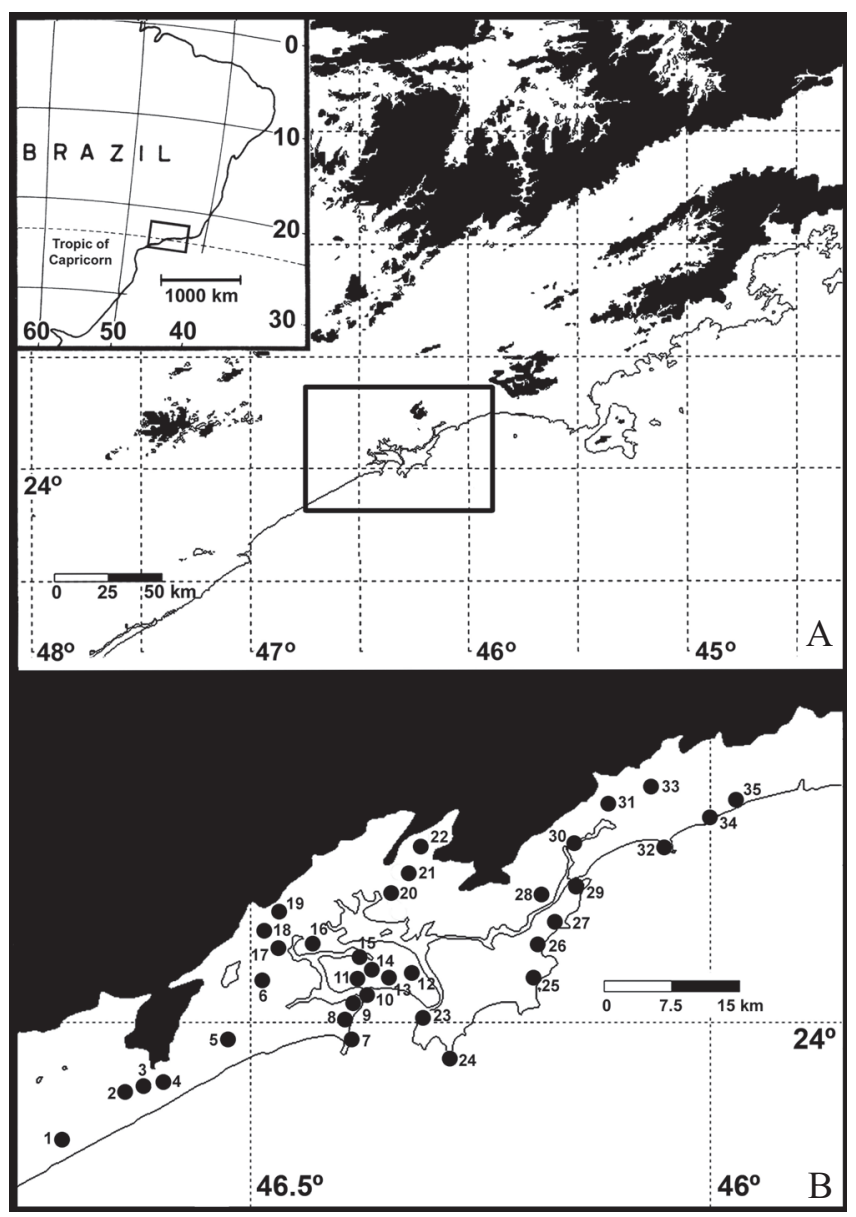

Fig. 1. Location of the Baixada Santista region in Southeastern Brazil. A. Enlarged view of the black rectangle in the South America map (top and left). B. Enlarged view of the black rectangle in A (the Baixada Santista region). Solid circles show the 35 most sampled sites in the Baixada Santista region (for details of each site see Table I). Black areas indicate altitudes above $1000 \mathrm{~m}$ in A, and above $500 \mathrm{~m}$ in B. Source: modified from IBGE 2009. 
Table I. Descriptors of sampled sites showed in the local map of Fig. 1.

\begin{tabular}{|c|c|c|c|}
\hline Number & Name & Municipality & Coordinates \\
\hline 1 & Balneário Itaóca & Mongaguá & $24^{\circ} 06^{\prime} \mathrm{S} ; 46^{\circ} 40^{\prime} \mathrm{W}$ \\
\hline 2 & Poço das Antas & Mongaguá & $24^{\circ} 05^{\prime} \mathrm{S} ; 46^{\circ} 37^{\prime} \mathrm{W}$ \\
\hline 3 & Serra de Mongaguá & Mongaguá & $24^{\circ} 05^{\prime} \mathrm{S} ; 4^{\circ} 36^{\prime} \mathrm{W}$ \\
\hline 4 & Cidade da Criança & Praia Grande & $24^{\circ} 04^{\prime} \mathrm{S} ; 46^{\circ} 35^{\prime} \mathrm{W}$ \\
\hline 5 & Restinga da Vila Caiçara & Praia Grande & $24^{\circ} 01^{\prime} \mathrm{S} ; 46^{\circ} 30^{\prime} \mathrm{W}$ \\
\hline 6 & Rio Branco & São Vicente & $23^{\circ} 56^{\prime} \mathrm{S} ; 46^{\circ} 28^{\prime} \mathrm{W}$ \\
\hline 7 & Fortaleza Itaipu & Praia Grande & $24^{\circ} 01^{\prime} \mathrm{S} ; 46^{\circ} 23^{\prime} \mathrm{W}$ \\
\hline 8 & Praia de Itaquitanduva & São Vicente & $24^{\circ} 00^{\prime} \mathrm{S} ; 46^{\circ} 23^{\prime} \mathrm{W}$ \\
\hline 9 & Morro do Japuí & São Vicente & $23^{\circ} 59^{\prime} \mathrm{S} ; 4^{\circ} 23^{\prime} \mathrm{W}$ \\
\hline 10 & Praia das Vacas & São Vicente & $23^{\circ} 59^{\prime} \mathrm{S} ; 46^{\circ} 22^{\prime} \mathrm{W}$ \\
\hline 11 & Morro dos Barbosas & São Vicente & $23^{\circ} 58^{\prime} \mathrm{S} ; 4^{\circ} 23^{\prime} \mathrm{W}$ \\
\hline 12 & Santos urban area & Santos & $23^{\circ} 57^{\prime} \mathrm{S} ; 46^{\circ} 18^{\prime} \mathrm{W}$ \\
\hline 13 & Orquidário/Morro da Nova Cintra & Santos & $23^{\circ} 58^{\prime} \mathrm{S} ; 46^{\circ} 20^{\prime} \mathrm{W}$ \\
\hline 14 & Morro do Voturuá & São Vicente/Santos & $23^{\circ} 57^{\prime} \mathrm{S} ; 46^{\circ} 21^{\prime} \mathrm{W}$ \\
\hline 15 & Jardim Casqueiro & Santos/Cubatão & $23^{\circ} 56^{\prime} \mathrm{S} ; 46^{\circ} 23^{\prime} \mathrm{W}$ \\
\hline 16 & Ilha Caraguatá & Cubatão & $23^{\circ} 55^{\prime} \mathrm{S} ; 46^{\circ} 23^{\prime} \mathrm{W}$ \\
\hline 17 & Manoel da Nóbrega Highway & Cubatão & $23^{\circ} 55^{\prime} \mathrm{S} ; 46^{\circ} 27^{\prime} \mathrm{W}$ \\
\hline 18 & Rio Cubatão valley & Cubatão & $23^{\circ} 55^{\prime} \mathrm{S} ; 46^{\circ} 29^{\prime} \mathrm{W}$ \\
\hline 19 & Anchieta Highway & São Vicente/Cubatão & $23^{\circ} 53^{\prime} \mathrm{S} ; 46^{\circ} 28^{\prime} \mathrm{W}$ \\
\hline 20 & Trapucaia Farm & Santos & $23^{\circ} 52^{\prime} \mathrm{S} ; 46^{\circ} 20^{\prime} \mathrm{W}$ \\
\hline 21 & Rio Quilombo valley & Santos & $23^{\circ} 50^{\prime} \mathrm{S} ; 46^{\circ} 19^{\prime} \mathrm{W}$ \\
\hline 22 & Upper Rio Quilombo & Santos & $23^{\circ} 49^{\prime} \mathrm{S} ; 46^{\circ} 18^{\prime} \mathrm{W}$ \\
\hline 23 & Praia do Góes & Guarujá & $24^{\circ} 00^{\prime} \mathrm{S} ; 46^{\circ} 18^{\prime} \mathrm{W}$ \\
\hline 24 & Forte dos Andradas & Guarujá & $24^{\circ} 01^{\prime} \mathrm{S} ; 46^{\circ} 17^{\prime} \mathrm{W}$ \\
\hline 25 & Praia de Pernambuco & Guarujá & $23^{\circ} 57^{\prime} \mathrm{S} ; 46^{\circ} 11^{\prime} \mathrm{W}$ \\
\hline 26 & Praia do Iporanga & Guarujá & $23^{\circ} 53^{\prime} \mathrm{S} ; 46^{\circ} 09^{\prime} \mathrm{W}$ \\
\hline 27 & Praia do Camburi & Guarujá & $23^{\circ} 52^{\prime} \mathrm{S} ; 46^{\circ} 11^{\prime} \mathrm{W}$ \\
\hline 28 & Caiubura & Bertioga & $23^{\circ} 52^{\prime} \mathrm{S} ; 4^{\circ} 11^{\prime} \mathrm{W}$ \\
\hline 29 & Morro da Armação & Guarujá & $23^{\circ} 51^{\prime} \mathrm{S} ; 4^{\circ} 08^{\prime} \mathrm{W}$ \\
\hline 30 & Restinga de Bertioga & Bertioga & $23^{\circ} 49^{\prime} \mathrm{S} ; 46^{\circ} 09^{\prime} \mathrm{W}$ \\
\hline 31 & Usina Itatinga & Bertioga & $23^{\circ} 46^{\prime} \mathrm{S} ; 46^{\circ} 06^{\prime} \mathrm{W}$ \\
\hline 32 & Praia do Indaiá & Bertioga & $23^{\circ} 49^{\prime} \mathrm{S} ; 46^{\circ} 02^{\prime} \mathrm{W}$ \\
\hline 33 & Fazenda Acaraú & Bertioga & $23^{\circ} 45^{\prime} \mathrm{S} ; 46^{\circ} 02^{\prime} \mathrm{W}$ \\
\hline 34 & Praia de Itaguaré & Bertioga & $23^{\circ} 46^{\prime} \mathrm{S} ; 45^{\circ} 57^{\prime} \mathrm{W}$ \\
\hline 35 & Praia de Guaratuba & Bertioga & $23^{\circ} 45^{\prime} \mathrm{S} ; 45^{\circ} 53^{\prime} \mathrm{W}$ \\
\hline
\end{tabular}

\section{RESULTS AND DISCUSSION}

A total of 538 butterfly species were recorded in the Baixada Santista region (Appendix I) representing about 16\% of the Brazilian butterfly fauna, and $34 \%$ of the known butterfly fauna for the state of São Paulo (Brown \& Freitas 1999). These numbers are in accordance with the expected richness of the region (according to Brown \& Freitas 2000b), and considering the large sampling effort, this list can be considered relatively complete (but see also the next sections). From the total of 538 species, $340(63 \%)$ are Papilionoidea and 198 (37\%) are Hesperioidea. The best represented family in the study area is Hesperiidae, with 198 species, followed by Nymphalidae with 179 species (Appendix I). These two families are the richest in all Neotropical sites surveyed to date, followed by Lycaenidae, Riodinidae, Pieridae and Papilionidae, the latter two with much lower richness (see general site lists compiled in Brown \& Freitas 1999, 2000b; Brown 2005). 
This total of 538 species is appreciably higher than the number of species found in some of the lists from similar biomes farther south, such as Blumenau (376 species) in Santa Catarina, and Maquiné (292 species) in Rio Grande do Sul (Iserhard \& Romanowski 2004; OHHM and AVLF, unpublished data). Some sites with richness similar to Baixada Santista can be found in the southern sector of the Atlantic Forest in Paraná and Santa Catarina states, such as Joinville with about 757 species already recorded, Jaraguá do Sul with about 540 species, and Curitiba with 528 species (Mielke 1996; Carlos G. C. Mielke, OHHM and AVLF, unpublished data). However, the number of species recorded at Baixada Santista is well below the number recorded in more tropical areas in Rio de Janeiro and Espírito Santo states, where some sites can have over 800 species (Brown \& Freitas 2000a, b; Brown 2005). The species richness seems to be higher also in some well sampled sites in the seasonal semideciduous forests in the interior, such as the Mata da Santa Genebra (702 species) and Ribeirão Cachoeira (567 species) in São Paulo state, Yacutinga (572 species) and Iguazú (652 species) in Misiones (Northern Argentina), and also in complex mosaic landscapes of deep valleys and high mountains in localities across several southeastern states, such as the Serra do Japi in São Paulo (679 species), Poços de Caldas in Minas Gerais (577 species) and Itatiaia in Rio de Janeiro (914 species) (Zikán \& Zikán 1968; Ebert 1969; Brown 1992; Brown \& Freitas 2000b, 2002b; Bustos 2008, 2009). It is important to note that none of the species collected in this study has been considered threatened of extinction in the Brazilian Red List (Machado et al. 2008).

Species richness. The species richness of the family Nymphalidae at the Baixada Santista is considered very accurate; we expect to have very few additional records to the list. For example, the nymphalids Eunica eurota dolores (Prittwitz, 1871) (Biblidinae), Archeuptychia cluena (Drury, 1782) (Satyrinae), Cissia myncea (Cramer, 1780) (Satyrinae), and Scada karschina karschina (Herbst, 1792) (Danainae) occur in sites less than $20 \mathrm{~km}$ north and east of the study region in the same biome (in lowland and submontane rain forests; AVLF and RBF, pers. obs.), and could well be present in small populations in the mountain slopes north of Bertioga, including the Usina Itatinga and Fazenda Acaraú (see Fig. 1).

Based on museum collections and field experience of the authors, very few new records would also be expected in Pieridae and Papilionidae. The few additions might include the papilionids Protographium asius (Fabricius, 1781) and Mimoides lysithous (Hübner, 1821), both occurring north and south of Baixada Santista and also recorded in neighbor mountain sites. In the Pieridae, some migratory and widespread species could still be added to the list, including Anteos clorinde (Godart, [1824]) and Phoebis neocypris (Hübner, [1823]). Montane species could also appear in winter months together with the already recorded Catasticta bithys (Hübner, [1831]) and Pereute antodyca (Boisduval, 1836). These additional records might include Theochila maenacte itatiayae (Foetterle, 1902) (recorded feeding on flowers in Ubatuba, northern São Paulo, at sea level) and Hesperocharis erota (Lucas, 1852), two species commonly found in the mountains above $800 \mathrm{~m}$ around the study region.

In the remaining three families, additions are expected to be greater. The Lycaenidae may grow up to more than 70 species, and the Riodinidae to near 60 species (see Brown \& Freitas $2000 \mathrm{~b}$ and data in the present work). Examples of species of Riodinidae recorded less than $50 \mathrm{~km}$ north and east of the study area includes Emesis ocypore zelotes Hewitson, 1872, E. neemias Hewitson, 1872, E. elegia Stichel, 1929, Isapis agyrtus abydus Stichel 1929, Aricoris constantius (Fabricius, 1793), Panaropsis inaria (Westwood, 1851), Calospila apotheta (H. W. Bates, 1868) and Stalachtis phlegia susanna (Fabricius, 1787). In the Hesperiidae the increase may also be significant, especially due to the low sampling of the fast flying Pyrrhopyginae for the region, and up to 10 species could be added to the list.

Several studies propose that the local number of species can be predicted based on surrogates of total butterfly richness (Beccaloni \& Gaston 1995; Brown \& Freitas 2000b). In that sense, the predicted richness for the Baixada Santista region based on the Ithomiini (4.3-4.6\% of total fauna) and Nymphalidae (25-29\% of total fauna) as surrogates would be between 558 and 660 species, a figure above the observed total of 538 species. If the above predictions of probable additions to each family are confirmed, the list of butterflies for the Baixada Santista would reach approximately 570 species, a number near that predicted based on Ithomiini richness only. However, if we are to make a prediction based on surrogates, and use the Nymphalidae as the best surrogate assuming that this is a well sampled group, and that an entire family is a better surrogate than a tribe, then it would be fair to assert that we have collected only $81.7 \%$ of the total butterfly fauna of the Baixada Santista. Therefore, even if our list is considered enough to provide a clear picture of the faunistic composition in the study region, several new records may be expected to be added to the list in all six families (in different proportions) with further field work in some of the less surveyed sites.

Taxonomic composition. In the present study, the diversity of larger butterfly groups follow the pattern reported in the total list of Brazilian butterflies, where Hesperiidae is the richest family, followed by Nymphalidae (Brown \& Freitas 1999 and Table II). This pattern was also reported in other relatively complete inventories in the Neotropics, showing Hesperiidae as the best represented butterfly group in any well surveyed locality, followed by the Nymphalidae (Brown \& Freitas 2000b). However, in short term studies with low sampling effort there has been a clear numerical dominance of Nymphalidae (Motta 2002; Iserhard \& Romanowski 2004; Duarte \& Almeida 2006; Marchiori \& Romanowski 2006), likely due to the fact that they are easily captured and identified in the field. The Hesperiidae, Lycaenidae and Riodinidae, all including many small and inconspicuous species, require more effort to be adequately sampled. Because species of these three groups are difficult to identify, they are also usu- 

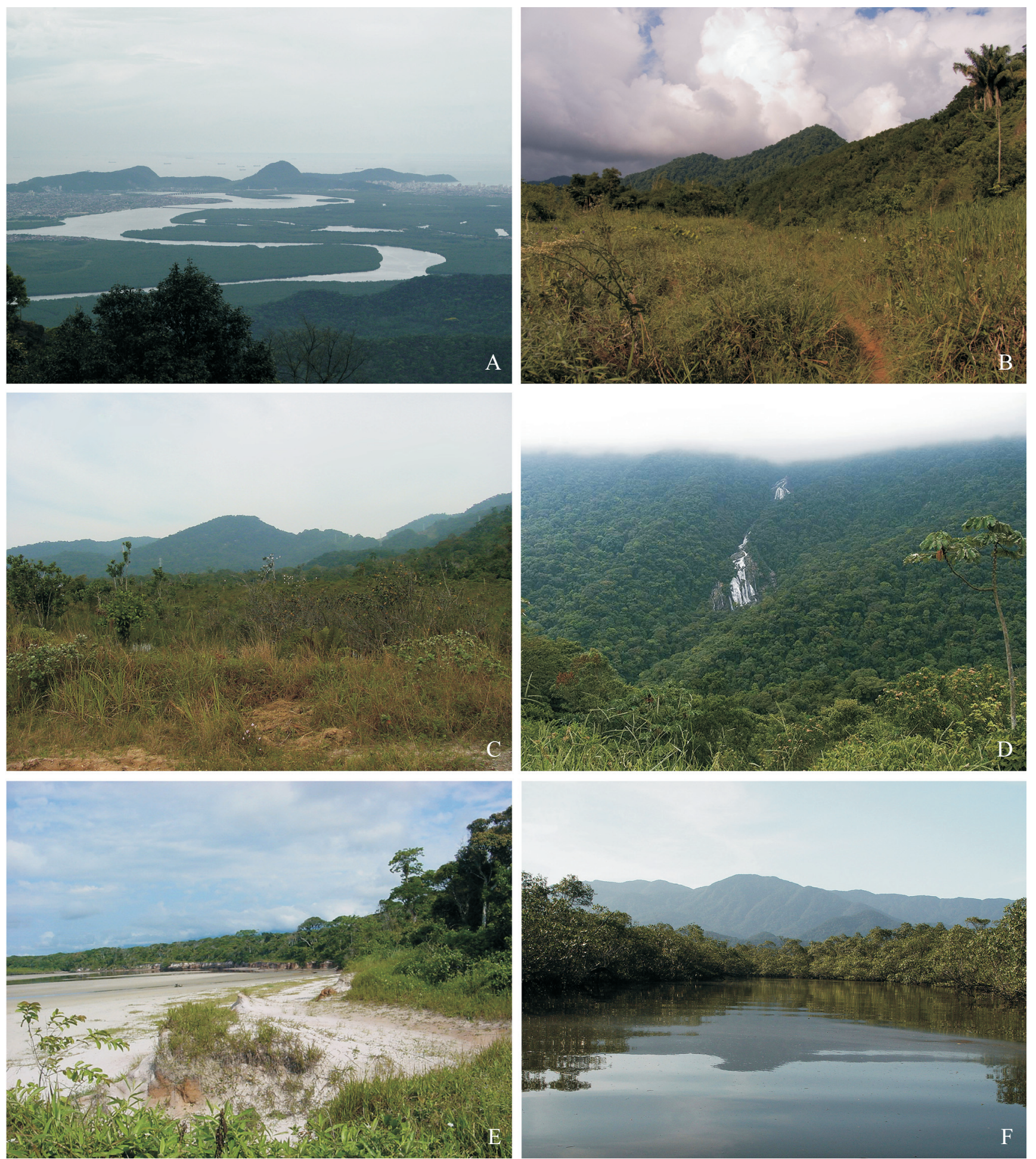

Fig. 2. Overview of the main landscapes in the Baixada Santista region. For vegetation description and site details see text and Table I. A. General view of the region showing the large mangroves: hills in the horizon are the Japuí-Xixová State Park; B. Secondary open vegetation and lowland rainforest: Morro do Japuí; C. Restinga vegetation: Bertioga; D. Submontane dense rainforest: slopes near Fazenda Acaraú; E. Dune and restinga vegetation: Praia de Itaguaré; F. Mangroves: Praia de Itaguaré.

ally undersampled, or not even considered in some studies (e.g. Almeida et al. 1986; Paz et al. 2008). We believe that a higher numerical dominance of the Hesperiidae is expected in all complete or near-complete butterfly surveys.
Concerning the Lycaenidae and Riodinidae, the pattern of richness reported in the present list is not the same of that observed in the total Brazilian list, where the latter is richer than the former (Table II). In a comparative analysis, 
Lycaenidae is richer than Riodinidae in most southern Atlantic Forest sites and in the montane forests, with the only remarkable exception being Joinville, in Santa Catarina state (Table II). In fact, the richness of Riodinidae at a given site has been shown to be positively correlated with the mean temperature of the site (Brown 2005). This may explain why this family is better represented in warmer forests of northern Atlantic Forest (Brown \& Freitas 2000b and Table II), and in several Amazonian sites (Brown \& Freitas 1999, 2002a; Brown 2005).

\section{CONCLUSIONS}

The butterfly fauna of the Baixada Santista region deserves attention (i.e. continuing studies and long-range conservation strategies) even if no threatened species have been recorded in the present study. The entire area shows a unique combination of different habitats and geography that includes deep valleys, expansive mangroves, high mountains and lowland plains, which provide conditions for the presence of a rich and diverse fauna combining elements from

Table II. Diversity and community composition of butterflies recorded in Brazil, in São Paulo State, and in 22 sites in the Atlantic Forest domain. All sites are in Brazil except Yacutinga and Iguazú, located in Northern Argentina. Asterisks indicate the richest butterfly family in each site.

\begin{tabular}{|c|c|c|c|c|c|c|c|}
\hline & Hesperiidae & Papilionidae & Pieridae & Lycaenidae & Riodinidae & Nymphalidae & Total \\
\hline Brazil - total list ${ }^{1,2}$ & $1165^{*}$ & 69 & 65 & 420 & 761 & 788 & 3268 \\
\hline São Paulo ${ }^{1,2,3}$ & $689^{*}$ & 35 & 46 & 206 & 222 & 389 & 1587 \\
\hline \multicolumn{8}{|l|}{ Coastal Brazil (southern) } \\
\hline Baixada Santista ${ }^{4,5}$ & $198^{*}$ & 18 & 29 & 65 & 49 & 179 & 538 \\
\hline Joinville ${ }^{4,6}$ & $364 *$ & 21 & 31 & 68 & 86 & 187 & 757 \\
\hline Jaraguá do $\mathrm{Sul}^{7}$ & $237^{*}$ & 19 & 36 & 47 & 47 & 165 & 551 \\
\hline Blumenau $^{8}$ & 112 & 13 & 33 & 26 & 25 & $167 *$ & 376 \\
\hline Maquiné ${ }^{9}$ & 97 & 13 & 24 & 35 & 19 & $104 *$ & 292 \\
\hline \multicolumn{8}{|l|}{ Coastal Brazil (northern) } \\
\hline Santa Teresa ${ }^{4,10}$ & $322 *$ & 17 & 36 & 64 & 86 & 244 & 769 \\
\hline Linhares $^{4}$ & $376^{*}$ & 19 & 25 & 92 & 105 & 218 & 835 \\
\hline Xerém ${ }^{4}$ & 131 & 22 & 29 & 43 & 60 & $177^{*}$ & 462 \\
\hline Rio de Janeiro $4,24,25$ & $250^{*}$ & 42 & 31 & 133 & 80 & 168 & 697 \\
\hline \multicolumn{8}{|l|}{ Montane forests } \\
\hline Itatiaia $^{4,11}$ & $366^{*}$ & 22 & 38 & 144 & 116 & 228 & 914 \\
\hline Serra do Japi ${ }^{3,4,12}$ & $253^{*}$ & 19 & 36 & 111 & 52 & 208 & 679 \\
\hline Poços de Caldas ${ }^{4,13}$ & $224 *$ & 16 & 35 & 87 & 47 & 168 & 577 \\
\hline Morro Grande $\mathrm{e}^{14,15}$ & $198^{*}$ & 16 & 35 & 54 & 49 & 188 & 540 \\
\hline Curitiba ${ }^{6,16}$ & $233^{*}$ & 14 & 30 & 53 & 44 & 154 & 528 \\
\hline \multicolumn{8}{|l|}{ Semideciduous forests } \\
\hline Santa Genebra ${ }^{3,4,17}$ & $311^{*}$ & 17 & 28 & 91 & 42 & 213 & 702 \\
\hline Ribeirão Cachoeiraa ${ }^{4,15,17}$ & $245^{*}$ & 14 & 26 & 75 & 38 & 169 & 567 \\
\hline Morro do Diabo 3,18 & $197 *$ & 15 & 19 & 35 & 38 & 156 & 460 \\
\hline Yacutinga $^{19}$ & $248^{*}$ & 12 & 21 & 68 & 49 & 174 & 572 \\
\hline Iguazú ${ }^{20}$ & $283^{*}$ & 18 & 30 & 72 & 60 & 189 & 652 \\
\hline \multicolumn{8}{|l|}{ Cerrado áreas } \\
\hline Brasília $^{21,22}$ & $335^{*}$ & 16 & 26 & 112 & 137 & 213 & 839 \\
\hline Belo Horizonte $^{4}$ & $170^{*}$ & 14 & 30 & 79 & 35 & 159 & 487 \\
\hline Uberlândia $^{23}$ & 52 & 8 & 17 & 36 & 28 & $110^{*}$ & 251 \\
\hline
\end{tabular}

${ }^{1}$ Brown \& Freitas (1999); ${ }^{2}$ M. Duarte (unpublished data); ${ }^{3}$ Brown \& Freitas (unpublished data); ${ }^{4}$ Brown \& Freitas (2000b); ${ }^{5}$ Present study; ${ }^{6}$ O. H. H. Mielke \& C. G. C. Mielke (unpublished); ${ }^{7}$ A. V. L. Freitas unpublished (data compiled from early lists by Fritz Hoffmann); ${ }^{8}$ O. H. H. Mielke \& A. V. L. Freitas (unpublished data); ${ }^{9}$ Iserhard \& Romanowski (2004); ${ }^{10}$ Brown \& Freitas (2000a); ${ }^{11}$ Zikán \& Zikán (1968); ${ }^{12}$ Brown (1992); ${ }^{13}$ Ebert (1969); ${ }^{14}$ Uehara-Prado et al. (2004); ${ }^{15}$ Uehara-Prado, Brown \& Freitas (unpublished); ${ }^{16}$ Mielke (1996); ${ }^{17}$ Brown \& Freitas (2002b); ${ }^{18}$ Mielke \& Casagrande (1998); ${ }^{19}$ Bustos (2008); ${ }^{20}$ Bustos (2009); ${ }^{21}$ Emery et al. (2006); ${ }^{22}$ Mielke et al. (2008); ${ }^{23}$ Motta (2002); ${ }^{24}$ Duarte et al. (2010); ${ }^{25}$ Monteiro et al. (2010). 
both the north and the south of Brazil. This combination can be found again farther south, in the Iguape-Cananéia region, near the border between the States of São Paulo and Paraná, but in that area the temperature drops near freezing levels several times during the winter months, a feature that could explain the absence of several of the tropical species observed in the Baixada Santista region, and that contributes to its uniqueness.

It is clear to us that, even with the large amount of information that exists for the Brazilian Atlantic Forest butterflies (see Brown \& Freitas 2000a, b and Santos et al. 2008) there are relatively few well sampled sites to allow comparative studies. Concentrated efforts to generate other lists of species are needed to help understand the distribution patterns of butterfly richness along the various environmental gradients of this endangered Biome (see also Duarte et al. 2010; Monteiro et al. 2010).

\section{ACKNOWLEDGMENTS}

Keith Brown helped in various phases of this work, including field trips and discussions. We also thank Keith Brown, Gerardo Lamas and Bob Robbins for helping with identifications. Several colleagues helped with the field work, and we are grateful to all of them. We acknowledge the invaluable assistance of the Instituto Florestal in obtaining permission to sample in protected areas. AVLF thanks FAPESP (grants 00/01484-1 and 04/05269-9, and the BIOTA-FAPESP Program grant 98/05101-8), the Brazilian CNPq (fellowship 300282/2008-7) and the National Science Foundation (DEB-0527441). MD thanks FAPESP (02/138980 and 03/05895-4) and Pró-Reitoria de Pesquisa/USP/Projeto 1 for complementary grants.

\section{REFERENCES}

Almeida, G. S. S.; C. L. Souza \& E. E. Marques. 1986. Levantamento preliminar das espécies de borboletas (Rhopalocera) de ocorrência em Maringá (PR): I. Papilionoidea. Revista Unimar 8: 29-36.

Beccaloni, G. W. \& K. J. Gaston. 1995. Predicting the species richness of Neotropical forest butterflies: Ithomiinae (Lepidoptera: Nymphalidae) as indicators. Biological Conservation 71: 77-86.

Brown Jr., K. S. 1972. Maximizing daily butterfly counts. Journal of the Lepidopterists' Society 26: 183-196.

Brown Jr., K. S. 1991. Conservation of Neotropical environments: insects as indicators, p. 349-404. In: N. M. Collins \& J. A. Thomas (eds.). The conservation of insects and their habitats. London, Academic Press, $401 \mathrm{p}$.

Brown Jr., K. S. 1992. Borboletas da Serra do Japi: diversidade, habitats, recursos alimentares e variação temporal, p. 142-187. In: L. Morellato (ed.). História Natural da Serra do Japi: ecologia e preservação de uma área florestal no sudeste do Brasil. Campinas, Editora da Unicamp, $321 \mathrm{p}$.

Brown Jr., K. S. 1996. Diversity of Brazilian Lepidoptera: History of study, methods for measurements, and use as indicators for genetic, specific and system richness, p. 221-253. In: C. E. M. Bicudo \& N. A. Menezes (eds.). Biodiversity in Brazil: a first approach. São Paulo, CNPq/ Instituto de Botânica, $v+326 \mathrm{p}$.

Brown Jr., K. S. 2005. Geological, evolutionary and ecological bases of the diversification of Neotropical butterflies: implications for conservation, p. 166-201. In: E. Bermingham E.; C. W. Dick \& C. Moritz (eds.). Tropical rainforests: Past, Present and Future. Chicago, University of Chicago Press, 672 p.

Brown Jr., K. S. \& A. V. L. Freitas. 1999. Lepidoptera, p. 225-243. In: C. A. Joly \& C. E. M. Bicudo (orgs.). Biodiversidade do Estado de São Paulo, Brasil: Síntese do Conhecimento ao Final do Século XX. 5. Invertebrados terrestres. C. R. F. Brandão \& E. M. Cancello (eds.). São Paulo, FAPESP, xviii +279 pp.

Brown Jr., K. S. \& A. V. L. Freitas. 2000a. Diversidade de Lepidoptera em Santa Teresa, Espírito Santo. Boletim do Museu de Biologia Mello Leitão, Nova Série, 11/12: 71-116.

Brown Jr., K. S. \& A. V. L. Freitas. 2000b. Atlantic Forest butterflies: indicators for landscape conservation. Biotropica 32: 934-956.

Brown Jr., K. S. \& A. V. L. Freitas. 2002a. Diversidade biológica no Alto Juruá: avaliação, causas e manutenção, p. 33-42; plates 13-16. In: M. M. C. da Cunha \& M. B. Almeida (orgs.). Enciclopédia da floresta. O Alto Juruá: Práticas e Conhecimentos das Populações. São Paulo, Companhia das Letras, $735 \mathrm{p}$.

Brown Jr., K. S. \& A. V. L. Freitas. 2002b. Butterfly communities of urban forest fragments in Campinas, São Paulo, Brazil: structure, instability, environmental correlates, and conservation. Journal of Insect Conservation 6: 217-231.

Bustos, E. O. N. 2008. Diversidad de mariposas diurnas en la Reserva Privada Yacutinga, Provincia de Misiones, Argentina (Lepidoptera: Hesperioidea y Papilionoidea). Tropical Lepidoptera Research 18: 78-87.

Bustos, E. O. N. 2009. Mariposas diurnas (Lepidoptera: Papilionoidea y Hesperioidea) del Parque Nacional Iguazú, Provincia de Misiones, Argentina. Tropical Lepidoptera Research 19: 71-81.

Caldas, A. \& R. K. Robbins. 2003. Modified Pollard Transects for Assessing Tropical Butterfly Abundance and Diversity. Biological Conservation 110: $211-219$.

DAEE. Departamento de Águas e Energia Elétrica. 2009. Banco de dados Hidrometeorológicos. http://www.daee.sp.gov.br/hidrometeorologia/ index.htm. Accessed in 03.jul.2009.

Duarte, M. \& G. L. de Almeida. 2006. Aspectos gerais da biologia e ecologia de borboletas. p.97-104. In: J. M. D. Torezan (org.). O Parque Estadual Mata dos Godoy: Aspectos da biologia e ecologia. Londrina, Editora da Universidade Estadual de Londrina, 169 p.

Duarte, M. \& R. K. Robbins. 2010. Description and phylogenetic analysis of the Calycopidina (Lepidoptera, Lycaenidae, Theclinae, Eumaeini): a subtribe of detritivores. Revista Brasileira de Entomologia 54: 4565.

Duarte, M.; R. K. Robbins; A. V. L. Freitas; K. S. Brown Jr.; R. F. Monteiro; M. M. Casagrande; O. H. H. Mielke; M. S. Nascimento \& T. G. Alves 2010 (2009). Borboletas da Mata Atlântica do Estado do Rio de Janeiro: Lycaenidae (Lepidoptera). Arquivos do Museu Nacional do Rio de Janeiro 67: 291-302.

Ebert, H. 1969. On the frequency of butterflies in eastern Brazil, with a list of the butterfly fauna of Poços de Caldas, Minas Gerais. Journal of the Lepidopterists' Society 23(suppl. 3): 1-48.

Emery, E. O.; K. S. Brown Jr. \& C. E. G. Pinheiro. 2006. As borboletas (Lepidoptera, Papilionoidea) do Distrito Federal, Brasil. Revista Brasileira de Entomologia 50: 85-92.

Freitas, A. V. L. 1993. Biology and Population dynamics of Placidula euryanassa, a relict ithomiine butterfly (Lepidoptera: Ithomiinae). Journal of the Lepidopterists' Society 47: 87-105.

Freitas, A. V. L. 1996. Population biology of Heterosais edessa (Nymphalidae) and its associated Atlantic Forest Ithomiinae community. Journal of the Lepidopterists' Society 50: 273-289.

Freitas, A. V. L.; R. B. Francini \& K. S. Brown Jr. 2003. Insetos como indicadores ambientais, p. 125-151. In: L. Cullen Jr.; R. Rudran \& C. Valladares-Pádua (eds.). Métodos de estudos em biologia da conservação e manejo da vida silvestre. Curitiba, Editora da Universidade Federal do Paraná/Fundação O Boticário de Proteção à Natureza, 665 p.

Freitas, A. V. L.; I. R. Leal; M. Uehara-Prado \& L. Iannuzzi. 2006. Insetos como indicadores de conservação da paisagem, p. 357-384. In: 
C. F. D. Rocha; H. G. Bergallo; M. Van Sluys \&. M. A. S. Alves (eds.). Biologia da Conservação: Essências. São Carlos, RiMa Editora, $588 \mathrm{p}$.

Hall, J. P. W. 2005. A phylogenetic revision of Napaeina (Lepidoptera: Riodinidae: Mesosemiini). Washington, D.C., The Entomological Society of Washington, $236 \mathrm{p}$.

IBGE. Instituto Brasileiro de Geografia e Estatística. 2009. Base Cartográfica Integrada do Brasil ao Milionésimo Digital. http:// www.ibge.gov.br. Accessed in 03.jul.2009.

Iserhard, C. A. \& H. P. Romanowski. 2004. Lista de espécies de borboletas (Lepidoptera: Papilionoidea e Hesperioidea) da região do vale do rio Maquiné, Rio Grande do Sul, Brasil. Revista Brasileira de Zoologia 21: $649-662$

Kronka, F J. N.; M. A. Nalon; C. K. Matsukuma; M. M. Kanashiro; M. S. S. Iwane; M. Pavão; G. Durigan; L. M. P. R. Lima; J. R. Guillaumon; J. B. Baitello; S. C. Borgo; L. A. Manetti; A. M. F. Barradas; J. C. Fukuda; C. N. Shida; C. H. B. Monteiro; A. A. S. Pontinha; G. G. de Andrade; O. Barbosa \& A. P. Soares. 2005. Inventário Florestal da Vegetação Natural do Estado de São Paulo. vol. 1. São Paulo, Secretaria do Meio Ambiente, Instituto Florestal, Imprensa Oficial, 200 p.

Lamas, G. 2004. Checklist: Part 4A. Hesperioidea - Papilionoidea. In: J. B. Heppner (ed.). Atlas of Neotropical Lepidoptera. Gainesville, Association for Tropical Lepidoptera, Inc. Scientific Publishers. 439 p.

Lewinsohn, T. M. \& P. I. Prado. 2002. Biodiversidade brasileira: síntese do estado atual do conhecimento. São Paulo, Editora Contexto, 176p.

Lewinsohn, T. M.; A. V. L. Freitas \& P. I. Prado. 2005. Conservation of Terrestrial Invertebrates and Their Habitats in Brazil. Conservation Biology 19: 640-645.

Machado, A. B. M; G. M. Drummond \& A. P. Paglia. 2008. Livro VermeIho da Fauna Brasileira Ameaçada de Extinção. Volume I. Belo Horizonte, Editora Rona, 511 p.

Marchiori, M. O. \& H. P. Romanowski. 2006. Borboletas (Lepidoptera, Papilionoidea e Hesperioidea) do Parque Estadual do Espinilho e entorno, Rio Grande do Sul, Brasil. Revista Brasileira de Zoologia 23: 1029-037.

McGeoch, M. A. 1998. The selection, testing, and application of terrestrial insects as bioindicators. Biological Review 73: 181-201.

Mielke, C. G. C. 1996. Papilionoidea e Hesperioidea (Lepidoptera) de Curitiba e seus arredores, Paraná, Brasil, com notas taxonômicas sobre Hesperiidae. Revista Brasileira de Zoologia 11: 759-776.

Mielke, O. H. H. 2005. Catalogue of the American Hesperioidea: Hesperiidae (Lepidoptera). 6 vols. Curitiba, Sociedade Brasileira de Zoologia, $1536 \mathrm{p}$.

Mielke, O. H. H. \& M. M. Casagrande. 1998. Papilionoidea e Hesperioidea (Lepidoptera) do Parque Estadual do Morro do Diabo, Teodoro Sampaio, São Paulo, Brasil. Revista Brasileira de Zoologia 14: 967 1001

Mielke, O. H. H.; E. O. Emery \& C. E. G. Pinheiro. 2008. As borboletas Hesperiidae (Lepidoptera, Hesperioidea) do Distrito Federal, Brasil. Revista Brasileira de Entomologia 52: 283-288.

Monteiro, R. F.; A. V. L. Freitas; M. A. F. Costa-Filho; M. S. Nascimento; T. G. Alves; K. S. Brown Jr; O. H. H. Mielke; M. M. Casagrande \& M. Duarte. 2010 (2009). Borboletas da Mata Atlântica do Estado do Rio de Janeiro: Pieridae (Lepidoptera). Arquivos do Museu Nacional do Rio de Janeiro 67: 283-289.

Morellato, L. P. C. \& C. F. B. Haddad. 2000. Introduction: the Brazilian atlantic forest. Biotropica 32:786-792.

Motta, P. C. 2002. Butterflies from the Uberlândia region, Central Brazil: Species list and biological comments. Brazilian Journal of Biology 62: 151-163.

New, T. R. 1997. Are Lepidoptera an effective 'umbrella group' for biodiversity conservation? Journal of Insect Conservation 1: 5-12.

Paz, A. L. G.; H. P. Romanowski \& A. B. B. Morais. 2008. Nymphalidae, Papilionoidae e Pieridae (Lepidoptera: Papilionoidae) na Serra do Sudeste do Rio Grande do Sul, Brasil. Biota Neotropica 8: 20-29.

Petrone, P. 1965. Povoamento e caminhos nos séculos XVI e XVII, p. 1173. In: A. Azevedo (ed.). A Baixada Santista. Aspectos geográficos. Vol. II. Povoamento e População. São Paulo, Editora da Universidade de São Paulo, 214 p. +3 maps.

Ramos, R. R. \& A. V. L. Freitas. 1999. Population biology, wing color variation and ecological plasticity in Heliconius erato phyllis (Nymphalidae). Journal of the Lepidopterists' Society 53: 11-21.

Santos, E. C.; O. H. H. Mielke \& M. M. Casagrande. 2008. Inventários de borboletas no Brasil: estado da arte e modelo de áreas prioritárias para pesquisa com vistas à conservação. Natureza \& Conservação 6: 6890.

Santos, E. O. 1965. Características Climáticas, p. 95-150. In: A. Azevedo (ed.). A Baixada Santista. Aspectos geográficos. Vol. I. As Bases Fisicas. São Paulo, Editora da Universidade de São Paulo, 178 p. + 7 tabs. +3 maps.

SIGRH. Sistema Integrado de Gerenciamento de Recursos Hídricos de São Paulo. 2005. Banco de Dados Pluviométricos do Estado de São Paulo. http://www.sigrh.sp.gov.br. Accessed in: 01.jan.2005.

Tabarelli, M.; L. P. Pinto; J. M. C. Silva; M. Hirota \& L. Bedê. 2005. Challenges and opportunities for biodiversity conservation in the Brazilian Atlantic Forest. Conservation Biology 19: 695-700.

Uehara-Prado, M.; A. V. L. Freitas; R. B. Francini \& K. S. Brown Jr. 2004. Guia das Borboletas Frugívoras da Reserva Estadual do Morro Grande e região de Caucaia do Alto, Cotia (São Paulo). Biota Neotropica 4: $1-25$.

Uehara-Prado, M.; K. S. Brown Jr. \& A. V. L. Freitas. 2007. Species richness, composition and abundance of fruit-feeding butterflies in the Brazilian Atlantic Forest: comparison between a fragmented and a continuous landscape. Global Ecology and Biogeography 16: 43-54.

Veloso, H. P.; A. L. R. Rangel Filho \& J. C. A. Lima. 1991. Classificação da vegetação brasileira adaptada a um sistema universal. Rio de Janeiro, Instituto Brasileiro de Geografia e Estatística, 123 p.

Wahlberg, N.; J. Leneveu; U. Kodandaramaiah; C. Peña; S. Nylin; A. V. L. Freitas \& A. V. Z. Brower. 2009. Nymphalid butterflies diversify following near demise at the Cretaceous/Tertiary boundary. Proceedings of the Royal Society B 276: 4295-4302.

Willmott, K. R. 2003. The genus Adelpha: its systematics, biology and biogeography (Lepidoptera: Nymphalidae: Limenitidini). Gainesville, Scientific Publishers, viii + 322 p.

Zikán, J. F. \& W. Zikán. 1968. Inseto-Fauna do Itatiaia e da Mantiqueira. III. Lepidoptera. Pesquisa Agropecuária Brasileira 3: 45-109.

Received 20/7/2009; accepted 5/1/2011

Editor: Claudio J. B. de Carvalho 
Appendix I. Butterflies (Papilionoidea and Hesperioidea) from the Baixada Santista region. Number of species are provided within parenthesis for each major taxa. Total: 538 species.

Papilionoidea (340)

Papilionidae (18)

Papilioninae (18)

Leptocircini (4)

Eurytides dolicaon deicoon (C. Felder \& R. Felder, 1864)

Protesilaus protesilaus nigricornis (Staudinger, 1884)

Protesilaus telesilaus vitellus (Fruhstorfer, 1907)

Mimoides protodamas (Godart, 1819)

Troidini (7)

Battus polydamas polydamas (Linnaeus, 1758)

Battus polystictus galenus (Fruhstorfer, 1907)

Battus crassus crassus (Cramer, 1777)

Parides agavus (Drury, 1782)

Parides anchises nephalion (Godart, 1819)

Parides tros tros (Fabricius, 1793)

Parides zacynthus zacynthus (Fabricius, 1793)

Papilionini (7)

Heraclides anchisiades capys (Hübner, [1809])

Heraclides androgeus laodocus (Fabricius, 1793)

Heraclides hectorides (Esper, 1794)

Heraclides thoas brasiliensis (Rothschild \& Jordan, 1906)

Heraclides torquatus polybius (Swainson, 1823)

Pterourus menatius cleotas (Gray, 1832)

Pterourus scamander grayi (Boisduval, 1836)

Pieridae (29)

Dismorphiinae (8)

Dismorphia amphione astynome (Dalman, 1823)

Dismorphia astyocha Hübner, [1831]

Dismorphia crisia crisia (Drury, 1782)

Dismorphia melia (Godart, [1824])

Dismorphia thermesia (Godart, 1819)

Enantia lina psamathe (Fabricius, 1793)

Enantia limnorina (C.Felder \& R.Felder, 1865)

Enantia clarissa (Weymer, 1895)

Coliadinae (14)

Anteos menippe (Hübner, [1818])

Phoebis argante argante (Fabricius, 1775)

Phoebis philea philea (Linnaeus, 1763)

Phoebis sennae marcellina (Cramer 1777)

Rhabdodryas trite banksi (Breyer, 1939)

Aphrissa statira statira (Cramer, 1777)

Pyrisitia leuce leuce (Boisduval, 1836)

Pyrisitia nise tenella (Boisduval, 1836)

Eurema agave pallida (Chavannes, 1850)

Eurema deva deva (Doubleday, 1847)

Eurema albula sinoe (Godart, 1819)

Eurema elathea flavescens (Chavanes, 1850)

Eurema phiale paula (Röber, 1909)

Leucidia elvina (Godart, 1819)

Pierinae (7)

Archonias brassolis tereas (Godart, 1819)

Catasticta bithys (Hübner, [1831])

Pereute antodyca (Boisduval, 1836)

Melete lycimnia flippantha (Fabricius, 1793)

Glutophrissa drusilla drusilla (Cramer, 1777)

Leptophobia aripa balidia (Boisduval, 1836)

Ascia monuste orseis (Godart, 1819)
Lycaenidae (65)

Polyommatinae (3)

Leptotes cassius cassius (Cramer, 1775)

Hemiargus hanno hanno (Stoll, 1790)

Zizula cyna (W. H. Edwards, 1881)

Theclinae (62)

Brangas ca. getus (Fabricius, 1787)

Evenus regalis (Cramer, 1775)

Evenus satyroides (Hewitson, 1865)

Atlides cosa (Hewitson, 1867)

Atlides rustan (Stoll, 1790)

Pseudolycaena marsyas (Linnaeus, 1758)

Theritas triquetra (Hewitson, 1865)

Theritas hemon (Cramer, 1775)

Theritas lisus (Stoll, 1790)

Thereus sp.

Rekoa meton (Cramer, 1779)

Rekoa palegon (Cramer, 1780)

Rekoa marius (Lucas, 1857)

Rekoa stagira (Hewitson, 1867)

Arawacus meliboeus (Fabricius, 1793)

Arawacus ellida (Hewitson, 1867)

Ocaria thales (Fabricius, 1793)

Chlorostrymon simaethis (Drury, 1773)

Chlorostrymon telea (Hewitson, 1868)

Magnastigma hirsuta (Prittwitz, 1865)

Cyanophrys acaste (Prittwitz, 1865)

Cyanophrys herodotus (Fabricius, 1793)

Allosmaitia strophius (Godart, [1824])

Laothus phydela (Hewitson, 1867)

Janthecla armilla (H.H. Druce, 1907)

Janthecla aurora (H.H. Druce, 1907)

Janthecla flosculus (H.H. Druce, 1907)

Badecla badaca (Hewitson, 1868)

Lamprospilus orcidia (Hewitson, 1874)

Ziegleria hesperitis (Butler \& H. Druce, 1872)

Kisutam syllis (Godman \& Salvin, 1887)

Electrostrymon endymion (Fabricius, 1775)

Calycopis caulonia (Hewitson, 1877)

Calycopis gentilla (Schaus, 1902)

Calycopis janeirica (C. Felder, 1862)

Calycopis sp.

Strymon mulucha (Hewitson, 1867)

Strymon bazochii (Godart, [1824])

Strymon bubastus (Stoll, 1780)

Strymon oreala (Hewitson, 1868)

Strymon ziba (Hewitson, 1868)

Tmolus echion (Linnaeus, 1767)

Nicolaea besidia (Hewitson, 1868)

Ministrymon cruenta (Gosse, 1880)

Ministrymon azia (Hewitson, 1873)

Ministrymon sp.

Gargina caninius (H. H. Druce, 1907)

Theclopsis murex (H. H. Druce, 1907)

Ostrinotes ca. empusa (Hewitson, 1867)

Strephonota sphinx (Fabricius, 1775)

Panthiades hebraeus (Hewitson, 1867)

Thepytus echelta (Hewitson, 1867)

Oenomaus atesa (Hewitson, 1867)

Parrhasius polibetes (Stoll, 1781) 
Michaelus jebus (Godart, [1824])

Aubergina vanessoides (Prittwitz, 1865)

Iaspis talayra (Hewitson, 1868)

Celmia celmus (Cramer, 1775)

Celmia conoveria (Scahus, 1902)

Erora sp.

Chalybs hassan (Stoll, 1790)

Symbiopsis strenua (Hewitson, 1877)

Riodinidae (49)

Euselasiinae (5)

Euselasia hygenius occulta Stichel, 1919

Euselasia fervida fervidina Stichel, 1919

Euselasia eucerus (Hewitson, 1872)

Euselasia thucydides thucydides (Fabricius, 1793)

Euselasia clesa (Hewitson, 1856)

Riodininae (44)

Mesosemiini (7)

Mesosemia odice (Godart, [1824])

Mesosemia rhodia (Godart, [1824])

Mesosemia meeda Hewitson, 1858

Leucochimona icare matatha (Hewitson, 1873)

Voltinia phryxe (C. Felder \& R. Felder, 1865)

Voltinia cebrenia (Hewitson, [1873])

Cremna alector (Geyer, 1837)

Eurybiini (2)

Eurybia pergaea (Geyer, 1832)

Eurybia molochina hyacinthina Stichel, 1910

Riodinini (12)

Lyropteryx apollonia apollonia Westwood, 1851

Ancyluris aulestes pandama (Saunders, 1850)

Rhetus periander eleusinus Stichel, 1910

Panara soana soana Hewitson, 1875

Brachyglenis drymo (Godman \& Salvin, 1886)

Metacharis ptolomaeus (Fabricius, 1793)

Pheles atricolor (Butler, 1871)

Barbicornis basilis basilis Godart, [1824]

Syrmatia nyx (Hübner, [1817])

Charis cadytis Hewitson, 1866

Lasaia agesilas (Latreille, [1809])

Riodina lycisca lycisca (Hewitson, [1863])

Symmachiini (4)

Pirascca arbuscula mandosa (H. Druce, 1904)

Pirascca sagaris satnius (Dalman, 1823)

Pterographium sicora (Hewitson, 1875)

Stichelia bocchoris suavis (Stichel, 1911)

Helicopini (2)

Anteros lectabilis Stichel, 1909

Anteros renaldus notius Stichel, 1911

Nymphidiini (11)

Lemonias zygia zygia Hübner, [1807]

Juditha molpe (Hübner, [1808])

Synargis calyce (C. Felder \& R. Felder, 1862)

Synargis phliasus phliasus (Clerck, 1764)

Menander menander nitida (Butler, 1867)

Menander felsina (Hewitson, 1863)

Adelotypa malca (Schaus, 1902)

Nymphidium lisimon lisimon (Stoll, 1790)

Catocyclotis aemulius (Fabricius, 1793)

Theope terambus (Godart, [1824])

Theope lycaenina H. W. Bates, 1868
Incertae sedis (6)

Echydna chaseba (Hewitson, 1854)

Emesis fastidiosa Ménétriés, 1855

Emesis fatimella fatimella Westwood, 1851

Emesis mandana (Cramer, 1780)

Emesis diogenia Prittwitz, 1865

Emesis sp.

Nymphalidae (179)

Libytheinae (1)

Libytheana carinenta (Cramer, 1777)

Danainae (29)

Danaini (5)

Euploeina (2)

Lycorea halia discreta Haensch, 1909

Lycorea ilione ilione (Cramer, 1775)

Danaina (3)

Danaus eresimus plexaure (Godart, 1819)

Danaus erippus (Cramer, 1775)

Danaus gilippus gilippus (Cramer, 1775)

Ithomiini (24)

Tithoreina (1)

Aeria olena olena Weymer, 1875

Melinaeina (2)

Melinaea ethra (Godart, 1819)

Melinaea ludovica paraiya Reakirt, 1866

Mechanitina (3)

Methona themisto (Hübner, 1818)

Mechanitis lysimnia lysimnia (Fabricius, 1793)

Mechanitis polymnia casabranca Haensch, 1905

Napeogenina (2)

Epityches eupompe (Geyer, 1832)

Hypothyris ninonia daeta (Boisduval, 1836)

Ithomiina (4)

Placidina euryanassa (C. Felder \& R. Felder, 1860)

Ithomia agnosia zikani D'Almeida, 1940

Ithomia drymo Hübner, 1816

Ithomia lichyi lichyi D'Almeida, 1939

Oleriina (1)

Oleria aquata (Weymer, 1875)

Dirceniina (7)

Callithomia lenea xantho (C.Felder \& R. Felder, 1860)

Dircenna dero (Hübner, 1823)

Episcada clausina striposis Haensch, 1909

Episcada hymenaea hymenaea (Prittwitz, 1865)

Episcada philoclea (Hewitson, [1855])

Pteronymia euritea (Cramer, 1780)

Pteronymia carlia Schaus, 1902

Godyridina (4)

Hypoleria adasa adasa (Hewitson, [1855])

Heterosais edessa (Hewitson, [1855])

Pseudoscada acilla acilla (Hewitson, 1867)

Pseudoscada erruca (Hewitson, 1855)

Satyrinae (40)

Morphini (7)

Antirrhea archaea Hübner, [1822]

Morpho aega (Hübner, [1822])

Morpho anaxibia (Esper, 1801)

Morpho epistrophus (Fabricius, 1796)

Morpho helenor achillaena (Hübner, [1823])

Morpho menelaus (Linnaeus, 1758)

Morpho hercules (Dalman, 1823) 
Brassolini (11)

Brassolis astyra astyra Godart, [1824]

Brassolis sophorae sophorae (Linnaeus, 1758)

Caligo beltrao (Illiger, 1801)

Caligo brasiliensis brasiliensis (C. Felder, 1862)

Caligo illioneus illioneus (Cramer, 1775)

Caligo idomeneus ariphron Fruhstorfer, 1910

Catoblepia amphirhoe (Hübner, [1825])

Dasyophthalma creusa creusa (Hübner, [1821])

Eryphanis reevesi reevesi (Doubleday, [1849])

Opsiphanes invirae pseudophilon Fruhstorfer, 1907

Narope cyllastros Doubleday, [1849]

Haeterini (2)

Pierella lamia lamia (Sulzer, 1776)

Pierella nereis (Drury, 1782)

Elymniini (1)

Manataria hercyna (Hübner, [1821])

Satyrini (19)

Pronophilina (3)

Eteona tisiphone (Boisduval, 1836)

Praepedalioides amussis (Thieme, 1905)

Praepedalioides phanias (Hewitson, 1862)

Euptychiina (16)

Carminda paeon (Godart, [1824])

Chloreuptychia arnaca (Fabricius, 1776)

Euptychia ernestina Weymer, 1911

Euptychia westwoodi Butler, 1867

Euptychoides castrensis (Schaus, 1902)

Forsterinaria necys (Godart, [1824])

Forsterinaria quantius (Godart, [1824])

Godartiana muscosa (Butler, 1870)

Hermeuptychia hermes (Fabricius, 1775)

Pareuptychia ocirrhoe interjecta (D'Almeida, 1952)

Paryphthimoides phronius (Godart, 1824)

Splendeuptychia doxes (Godart, [1824])

Splendeuptychia hygina (Butler, 1877)

Taygetis laches marginata Staudinger, [1887]

Taygetis rufomarginata Staudinger, 1888

Yphthimoides renata (Stoll, 1780)

Charaxinae (16)

Anaeini (11)

Consul fabius drurii (Butler, 1874)

Hypna clytemnestra huebneri Butler, 1866

Siderone galanthis galanthis (Cramer, 1775)

Zaretis strigosus (Gmelin, [1790])

Fountainea ryphea phidile (Geyer, 1837)

Memphis appias (Hübner, 1825)

Memphis leonida editha (W. P. Comstock, 1961)

Memphis moruus stheno (Prittwitz, 1865)

Memphis acidalia victoria (H. Druce, 1877)

Memphis otrere (Hübner, [1825])

Memphis philumena corita (Fruhstorfer, 1916)

Preponini (5)

Archaeoprepona amphimachus pseudomeander (Fruhstorfer, 1906)

Archaeoprepona demophon thalpius (Hübner, [1814])

Archaeoprepona demophoon antimache (Hübner, [1819])

Archaeoprepona meander castorina (E. May, 1932)

Prepona pylene pylene Hewitson, [1854]

Biblidinae (26)

Biblis hyperia nectanabis (Fruhstorfer, 1909)
Catonephele acontius acontius (Linnaeus, 1771)

Catonephele numilia penthia (Hewitson, 1852)

Eunica maja maja (Fabricius, 1775)

Eunica sydonia sydonia (Godart, [1824])

Eunica volumna volumna (Godart, [1824])

Myscelia orsis (Drury, 1782)

Ectima thecla thecla (Fabricius, 1796)

Hamadryas amphinome amphinome (Linnaeus, 1767)

Hamadryas arete (Doubleday, 1847)

Hamadryas arinome obnubila (Fruhstorfer, 1916)

Hamadryas februa februa (Hübner, [1823])

Hamadryas feronia feronia (Linnaeus, 1758)

Hamadryas fornax fornax (Hübner, [1823])

Hamadryas epinome (C. Felder \& R. Felder, 1867)

Pyrrhogyra neaerea ophni Butler, 1870

Nica flavilla flavilla (Godart, [1824])

Temenis laothoe meridionalis Ebert, 1965

Dynamine agacles (Dalman, 1823)

Dynamine artemisia artemisia (Fabricius, 1793)

Dynamine athemon maeon (Doubleday, 1849)

Dynamine postverta postverta (Cramer, 1779)

Callicore astarte selima (Guenée, 1872)

Callicore pygas eucale (Fruhstorfer, 1916)

Diaethria clymena meridionalis (H. W. Bates, 1864)

Haematera pyrame pyrame (Hübner, [1819])

Apaturinae (3)

Doxocopa agathina vacuna (Godart, [1824])

Doxocopa laurentia laurentia (Godart, [1824])

Doxocopa kallina (Staudinger, 1886)

Cyrestinae (3)

Marpesia chiron chiron (Fabricius, 1775)

Marpesia petreus petreus (Cramer, 1776)

Marpesia zerynthia Hübner [1823]

Nymphalinae (22)

Coeini (4)

Colobura dirce dirce (Linnaeus, 1758)

Historis acheronta (Fabricius, 1775)

Historis odius dious Lamas, 1995

Smyrna blomfildia blomfildia (Fabricius, 1781)

Nymphalini (4)

Hypanartia bella (Fabricius, 1793)

Hypanartia lethe (Fabricius, 1793)

Vanessa braziliensis (Moore, 1883)

Vanessa myrinna (Doubleday, 1849)

Kallimini (5)

Anartia amathea roeselia (Eschscholtz, 1821)

Anartia jatrophae jatrophae (Linnaeus, 1763)

Junonia evarete (Cramer, 1779)

Siproeta epaphus trayja (Hübner, [1823])

Siproeta stelenes meridionalis (Fruhstorfer, 1909)

Melitaeini (9)

Chlosyne lacinia saundersi (Doubleday, [1847])

Anthanassa frisia hermas (Hewitson, 1864)

Eresia eunice esora Hewitson, 1857

Eresia lansdorfi (Godart, 1819)

Eresia perna perna Hewitson, 1852

Ortilia ithra (W. F. Kirby, 1900)

Ortilia orticas orticas (Schaus, 1902)

Tegosa claudina (Eschscholtz, 1821)

Telenassa teletusa teletusa (Godart, [1824]) 
Limenitidinae (13)

Adelpha serpa serpa (Boisduval, 1836)

Adelpha hyas hyas (Doyère, [1840])

Adelpha mythra (Godart, [1824])

Adelpha plesaure plesaure Hübner, 1823

Adelpha iphiclus ephesa (Ménétriés, 1857)

Adelpha melona pseudarete Fruhstorfer, 1915

Adelpha syma (Godart, [1824])

Adelpha cytherea aea (C. Felder \& R. Felder, 1867)

Adelpha viola viola Fruhstorfer, 1913

Adelpha capucinus velia (C. Felder \& R. Felder, 1867)

Adelpha thesprotia (C. Felder \& R. Felder, 1867)

Adelpha lycorias lycorias (Godart, [1824])

Adelpha cocala caninia Fruhstorfer, 1915

Heliconiinae (26)

Argynnini (1)

Euptoieta hegesia meridiana Stichel, 1938

Acraeini (10)

Actinote pellenea pellenea Hübner, [1821]

Actinote brylla Oberthür, 1917

Actinote carycina Jordan, 1913

Actinote pyrrha pyrrha (Fabricius, 1775)

Actinote melanisans Oberthür, 1917

Actinote genitrix D’Almeida, 1922

Actinote parapheles Jordan, 1913

Actinote canutia (Hopffer, 1874)

Actinote discrepans D’Almeida, 1958

Actinote surima surima (Schaus, 1902)

Heliconiini (15)

Agraulis vanillae maculosa (Stichel, [1908])

Dione juno juno (Cramer, 1779)

Dione moneta moneta (Hübner, [1825])

Dryadula phaetusa (Linnaeus, 1758)

Dryas iulia alcionea (Cramer, 1779)

Philaethria dido dido (Linnaeus, 1763)

Philaethria wernickei (Röber, 1906)

Eueides aliphera aliphera (Godart, 1819)

Eueides isabella dianasa (Hübner, [1806])

Eueides pavana Ménétriés, 1857

Heliconius besckei Ménétriés, 1857

Heliconius erato phyllis (Fabricius, 1775)

Heliconius ethilla narcaea Godart, 1819

Heliconius numata robigus Weymer, 1875

Heliconius sara apseudes (Hübner, [1813])

Hesperioidea - Hesperiidae (198)

Pyrrhopyginae (5)

Myscelus amystis epigona Herrich-Schäffer, 1869

Myscelus santhilarius (Latreille, [1824])

Elbella sp.

Elbella lamprus albociliata Mielke,1995

Pyrrhopyge charybdis semita Evans, 1951

Pyrginae (80)

Eudamini (38)

Aguna asander asander (Hewitson, 1867)

Astraptes creteus siges (Mabille, 1903)

Astraptes chiriquensis oenander (Hewitson, 1876)

Astraptes fulgerator fulgerator (Walch, 1775)

Astraptes talus (Cramer, 1777)

Autochton longipennis (Plötz, 1882)

Autochton neis (Geyer, 1832)
Autochton reflexus (Mabille \& Boullet, 1912)

Autochton zarex (Hübner, 1818)

Bungalotis midas (Cramer, 1775)

Celaenorrhinus eligius punctiger (Burmeister, 1878)

Celaenorrhinus similis Hayward, 1933

Cephise cephise (Herrich-Schäffer, 1869)

Chioides catillus catillus (Cramer, 1779)

Euryphellus euribates polygius (Latreille, [1824])

Drephalys phoenicoides (Mabille \& Boullet, 1919)

Epargyreus exadeus exadeus (Cramer, 1779)

Nascus paulliniae (Sepp, [1842])

Nascus phocus (Cramer, 1777)

Phanus australis L. D. Miller, 1965

Phocides pigmalion pigmalion (Cramer, 1779)

Phocides polybius phanias (Burmeister, 1880)

Polygonus leo pallida Röber, 1925

Polygonus savigny savigny (Latreille, 1824)

Polythrix caunus (Herrich-Schäffer, 1869)

Polythrix octomaculata (Sepp, [1844])

Proteides mercurius mercurius (Fabricius, 1787)

Salatis salatis (Stoll, 1782)

Typhedanus undulatus (Hewitson, 1867)

Urbanus albimargo takuta Evans, 1952

Urbanus dorantes dorantes (Stoll, 1790)

Urbanus doryssus albicuspis (Herrich-Schäffer, 1869)

Urbanus esmeraldus (Butler, 1877)

Urbanus esta Evans, 1952

Urbanus procne (Plötz, 1880)

Urbanus proteus proteus (Linnaeus, 1758)

Urbanus simplicius (Stoll, 1790)

Urbanus teleus (Hübner, 1821)

Pyrgini (42)

Achlyodes busirus rioja Evans, 1953

Achlyodes mithridates thraso (Hübner, [1807])

Anastrus obscurus Hübner, [1824]

Anastrus sempiternus simplicior (Möschler, 1877)

Anastrus tolimus robigus (Plötz 1884)

Camptopleura janthinus (Capronnier, 1874)

Chiomara asychis autander (Mabille, 1891)

Milanion clito (Fabricius, 1787)

Cycloglypha tisias (Godman \& Salvin, 1896)

Cycloglypha thrasibulus thrasibulus (Fabricius, 1793)

Ebrietas anacreon anacreon (Staudinger, 1876)

Gesta gesta (Herrich-Schäffer, 1863)

Gorgythion plautia (Möschler, 1877)

Gorgythion begga begga (Prittwitz, 1868)

Gorgythion beggina escalophoides Evans, 1953

Grais stigmaticus stigmaticus (Mabille, 1833)

Helias phalaenoides palpalis (Latreille, [1824])

Heliopetes omrina (Butler, 1870)

Milanion leucaspis (Mabille, 1878)

Mylon maimon (Fabricius, 1775)

Nisoniades castolus (Hewitson, 1878)

Nisoniades bipuncta (Schaus, 1902)

Nisoniades $\mathrm{sp}$.

Ouleus accendens accendens (Mabille, 1895)

Pellicia costimacula costimacula Herrich-Schäffer, 1870

Polyctor polyctor polyctor (Prittwitz, 1868)

Pyrgus orcynoides (Giacomelli, 1928)

Pyrgus orcus (Stoll, 1780) 
Pythonides lancea (Hewitson, 1868)

Pythonides tullia Evans, 1953

Quadrus cerialis (Stoll, 1782)

Sostrata bifasciata bifasciata (Ménétriés, 1829)

Sostrata cronion (C. Felder \& R. Felder, 1867)

Spathilepia clonius (Cramer, 1775)

Spioniades artemides (Stoll, 1782)

Staphylus incisus (Mabille, 1878)

Telemiades antiope antiope (Plötz, 1882)

Telemiades avitus (Stoll, 1781)

Telemiades epicalus Hübner, [1819]

Trina geometrina geometrina (C. R. Felder \& R. Felder, 1867)

Xenophanes tryxus (Stoll, 1780)

Zera zera zera (Butler, 1870)

Heteropterinae (1)

Dalla diraspes (Hewitson, 1877)

Hesperiinae (112)

Anatrytone mella (Godman, 1900)

Anthoptus epictetus (Fabricius, 1793)

Argon lota (Hewitson, 1877)

Arita arita (Schaus, 1902)

Artines aquilina (Plötz, 1882)

Callimormus saturnus (Herrich-Schäffer, 1869)

Callimormus corades (C. Felder, 1862)

Carystoides basoches (Latreille, [1824])

Carystus phorcus claudianus (Latreille, 1824)

Cobalopsis nero (Herrich-Schäffer, 1869)

Cobalopsis miaba (Schaus, 1902)

Cobalus virbius hersilia (Plötz, 1882)

Conga chydaea (Butler, 1877)

Corticea corticea (Plötz, 1882)

Corticea lysias potex Evans, 1955

Cymaenes tripunctus theogenis (Capronnier, 1874)

Cymaenes uruba uruba (Plötz, 1886)

Cymaenes gisca Evans, 1955

Cynea bistrigula (Herrich-Schäffer, 1869)

Cynea diluta (Herrich-Schäffer, 1869)

Cynea trimaculata (Herrich-Schäffer, 1869)

Cynea sp.1

Cynea sp.2

Damas clavus (Herrich-Schäffer, 1869)

Decinea decinea decinea (Hewitson, 1876)

Euphyes leptosema (Mabille, 1891)

Eutychide physcella (Hewitson, 1866)

Eutychide olympia (Plötz, 1882)

Enosis schausi Mielke \& Casagrande, 2002

Enosis uza pruinosa (Plötz, 1882)

Eutocus vetulus matildae (Hayward, 1941)

Flaccilla aecas (Stoll, 1781)

Hylephila phyleus phyleus (Drury, 1773)

Justinia kora (Hewitson, 1877)

Lamponia lamponia (Hewitson, 1876)

Ludens ludens (Mabille, 1891)

Lento lento (Mabille, 1878)

Lycas argentea (Hewitson, 1866)

Lychnuchoides ozias ozias (Hewitson, 1878)

Lychnuchus celsus (Fabricius, 1793)

Methionopsis ina (Plötz, 1882)

Metron chrysogastra hypodesma (Plötz, 1882)

Metron oropa (Hewitson, 1877)
Miltomiges cinnamomea (Herrich-Schäffer, 1869)

Mnasilus allubita (Butler, 1877)

Moeris striga striga (Geyer, 1832)

Morys compta compta (Butler, 1877)

Morys geisa geisa (Möschler, 1879)

Mucia zygia (Plötz, 1886)

Neoxeniades scipio scipio (Fabricius, 1793)

Niconiades cydia (Hewiston 1876)

Niconiades sp.

Naevolus orius orius (Mabille, 1883)

Nyctelius nyctelius nyctelius (Latreille, [1824])

Onophas columbaria distigma Bell, 1930

Orphe gerasa (Hewitson, 1867)

Orthos orthos hyalinus (Bell, 1930)

Panoquina evadnes (Stoll, 1781)

Panoquina hecebolus (Scudder, 1872)

Panoquina fusina viola Evans, 1955

Panoquina panoquinoides minima De Jong, 1983

Panoquina lucas lucas (Fabricius, 1793)

Panoquina ocola (W. H. Edwards, 1863)

Panoquina sp.

Papias phainis Godman, 1900

Paracarystus hypargyra (Herrich-Schäffer, 1869)

Paracarystus menestries menestries (Latreille, [1824])

Penicula cristatus (Bell, 1930)

Penicula subviridis (Plötz, 1886)

Perichares philetes aurina Evans, 1955

Perichares seneca seneca (Latreille, [1824])

Phanes almoda (Hewitson, 1866)

Phanes rezia (Plötz, 1882)

Pheraeus fastus (Hayward, 1939)

Polites vibex catilina (Plötz, 1886)

Pompeius pompeius (Latreille, [1824])

Psoralis stacara (Schaus, 1902)

Pyrrhopygopsis socrates socrates (Ménétriés, 1855)

Quasimellana nicomedes (Mabille, 1883)

Quinta cannae (Herrich-Schäffer, 1869)

Quinta locutia (Hewitson, 1876)

Repens repens Evans, 1955

Saliana esperi esperi Evans, 1955

Saliana saladin catha Evans, 1955

Saliana salius (Cramer, 1775)

Saliana triangularis (Kaye, 1914)

Saliana mathiolus (Herrich-Schäffer 1869)

Saliana sp.

Saturnus reticulata tiberius (Möschler, 1883)

Sodalia argyrospila (Mabille, 1876)

Sodalia coler (Schaus, 1902)

Synale hylaspes (Stoll, 1781)

Synapte malitiosa anistia (Plötz, 1882)

Talides sergestus (Cramer, 1775)

Tisias quadrata quadrata (Herrich-Schäffer 1869)

Tirynthia conflua (Herrich-Schäffer 1869)

Thracides cleanthes cleanthes (Latreille, [1824])

Thracides nanea nanea (Hewitson, 1867)

Thracides phidon (Cramer, 1779)

Turesis complanula (Herrich-Schäffer, 1869)

Vacerra bonfilius (Latreille, [1824])

Vehilius stictomenes stictomenes (Butler, 1877)

Vertica verticalis verticalis (Plötz, 1882)

Vettius artona (Hewitson, 1868) 
Vettius diversa diversa (Herrich-Schäffer, 1869)

Vettius lafrenaye lafrenaye (Latreille, [1824])

Vettius phyllus prona Evans, 1955

Vettius richardi (A. G. Weeks, 1906)
Vinius letis (Plötz, 1883)

Vinius tryhana istria Evans, 1955

Virga austrinus (Hayward, 1934)

Zariaspes mys (Hübner, [1808]) 